\title{
Adaptive Learning Strategies with Gamification to Enhance Learning Engagement
}

\author{
Siti Nurul Mahfuzah Mohamad ${ }^{1 *}$, Mohd Azran Mohd Salleh², Mohd Hakim \\ Abdul Hamid' ', Linda Khoo Mei Sui' and Che Ku Nuraini Che Ku Mohd' \\ 'Pervasive Computing and Educational Technology, Centre for Advanced Computing \\ Technology, Universiti Teknikal Malaysia Melaka, 76100 Durian \\ Tunggal Melaka, Malaysia; mahfuzah@utem.edu.my \\ ${ }^{2}$ Kolej Komuniti Selandar, Melaka, Malaysia
}

\begin{abstract}
Background/Objectives: In an adaptive learning strategy, the educator will decide what to teach manage and engage a student. Then, a student will get learning activities that suit their intelligence. Gamification is not an integral part of adaptive learning. However, adaptive learning using gamification can successfully organize to increase learning engagement. Methods/Statistical analysis: There are five phases involved in this study: (i) Determining Student Intelligence; (ii) Defining Learning Goal; (iii) Structuring Learner Experience; (iv) Analyze Suitable Game Elements and (v) Heutagogy Design Process. This study is designed for TVET students to collaborate, share the idea and discuss related issues to the context of the subject. This promotes critical thinking and communication skills among students. Participants involved in this study are undergraduate students from two TVET institutions in Malaysia. Findings: The findings demonstrate that students learn better and enhance students' engagement. Activities in the class used real projects as an alternative assessment. Students won several awards. Improvements/Applications: Through e-Learning competition, give students opportunities to reflect their learning in order to help them develop critical thinking skills.
\end{abstract}

Keywords: Adaptive Learning, Design Process, Gamification, Heutagogy, Multiple Intelligences

\section{Introduction}

It is important to understand on how to apply adaptive learning with gamification nowadays. In adaptive learning strategy, educator will decide what to teach manage and engage student. Then, student will get learning activities that suit to their intelligences. Gamification is not an integral part of adaptive learning. However, adaptive learning using gamification can successfully organize to increase learning engagement. Researchers have used this gamification method for few years already ${ }^{1-4}$. The goals were to provide gamified educational sites based on Multiple Intelligence (MI) theory as shown in Figure
1. Students took the MI Test before they accessed the learning materials. Nowadays, educators act as facilitator and guide students to perform the tasks. This initiative has sought to encourage students to work independently and cooperatively in teams as well as to encourage students to share their opinion and ideas with others.

\section{An Adaptive Learning Strategies with Gamification}

Learning is fun and its feel like gaming but not playing. Therefore, using the adaptive learning strategies with gamification makes student to have fun and at the same 

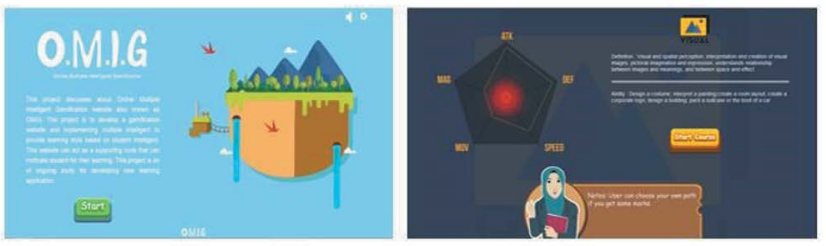

Figure 1. Gamified E-learning site based on students intelligence.

time, learn the lesson. Furthermore, using this method can help students to improve learning engagement, suit students' learning style, and provide more adaptive learning. There are five phases involved in this study:

\subsection{Determining Students Intelligences}

Every student has at least two or more intelligences ${ }^{5}$. $\operatorname{In}^{6}$ stressed that understanding target students is the main factor to succeed in education. $\operatorname{In}^{7}$ applied adaptation and personalization through the Intelligent Tutorial System to offer different interface elements to students. They used different techniques to suit students' preference as well as define user profile and learning content that allow the personalization. In $^{-}$also applied the theory of MI in her study to motivate student learning and provide suitable teaching tools that match the students' strength. $\operatorname{In}^{9}$ suggested that different types of students may be drawn towards gamification in different ways. $\mathrm{In}^{10} \underline{ }$ also applied adaptive learning that seeks to personalize learning. Students' profiles were identifying from the results of the responsive analysis obtained through the MI Test as shown in Figure 2.

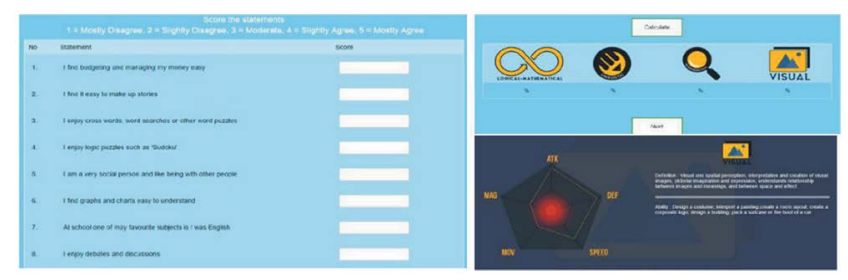

Figure 2: MI test.

\subsection{Defining Learning Goals}

It is important to define the learning goals in education; otherwise, all the game designs applied are meaningless. During this phase, educators need to identify what the student wants to achieve. Identify suitable assessment as well as adapting curriculum to the learning outcomes throughout the learning process. Thus, it is important to engage student learning, where educators need to design creative activities with proper game elements. Specifically, the games elements can help students to learn how to work together.

\subsection{Structuring Learner Experience (Content and Activities)}

Technology is often transforming. In the adaptive learning concept, the adaptive design interface is based on student intelligences. Through adaptive learning, it will allow students to progress at their own pace, increase student engagement, improve student performance, as well as provide effective learning and better learning experience. In the context of gamification, educators need to effectively use suitable game elements that can be applied in the teaching and learning process to cater different styles of learning. However, it is hard to decide the required level of adaptability ${ }^{10}$.

\subsection{Analyse Suitable Game Elements}

The selection of game mechanics is based on the personalisation of the learner. If learners have strength in visual, the avatar and course map are created to be suitable to their learning. According to ${ }^{11}$ the most popular game design interfaces are as follows: (i) leader board (46\%); (ii) fantasy (14\%); (iii) avatar; and (iv) knowledge map (5\%). In ${ }^{12}$ suggested the global priorities distribution for gamification elements with three interaction dimension (Learner-Content, Learner-Instructor and LeanerLearner). Based on result from $\frac{13}{}$ there are twelve (12) game elements can be use in teaching and learning as shown in Table 1.

Table 1. Top twelve of game elements

\begin{tabular}{|c|c|c|}
\hline No & $\begin{array}{l}\text { Gamification Instruction } \\
\text { Interaction Dimension }\end{array}$ & $\begin{array}{l}\text { Gamification } \\
\text { Elements }\end{array}$ \\
\hline \multirow{4}{*}{1} & \multirow{4}{*}{ Learner-Content } & Virtual Goods \\
\hline & & Wally's Games \\
\hline & & Memory Game \\
\hline & & Check Points \\
\hline 2 & $\begin{array}{l}\text { Learner-Instructor Trophies- } \\
\text { Badges Progress Bar }\end{array}$ & Rewards \\
\hline \multirow{5}{*}{3} & \multirow{5}{*}{ Learner-Learner } & Redeemable Points \\
\hline & & Skill Points \\
\hline & & Peer grading \\
\hline & & $\begin{array}{l}\text { Peer Emoticon } \\
\text { Feedback }\end{array}$ \\
\hline & & Team Leaderboard \\
\hline
\end{tabular}




\subsection{Heutagogy Design Process}

It is important for educator to understand the Heutagogy Design Process. Defining the learning goals and guide students toward the technology that can allow every student to explore and collaborate. Student will learn using the learning materials that suit to their intelligence and giving the student freedom to create. Table 2 shows the heutagogy design process applied in this study $\underline{\underline{14}-\underline{15}}$.

Table 2. Heutagogy design process

\begin{tabular}{|c|c|c|c|}
\hline Step & $\begin{array}{c}\text { Heutagogy } \\
\text { Design } \\
\text { Process }\end{array}$ & Activities & $\begin{array}{c}\text { Types of } \\
\text { Intelligences }\end{array}$ \\
\hline \multirow{3}{*}{1} & \multirow{3}{*}{ Explore } & 1. Online Whiteboard 1. & 1. Visual Spatial \\
\hline & & 2. Online Presentation 2 . & 2. Verbal Linguistic \\
\hline & & 3. Mind Map maker & 3. Intrapersonal \\
\hline \multirow{4}{*}{2} & \multirow{4}{*}{ Create } & 1. Drawing Avatar & 1. Visual Spatial \\
\hline & & 2.Poster Designing & 2. Verbal Linguistic \\
\hline & & 3. Competition & \\
\hline & & 4. Writing & \\
\hline \multirow{4}{*}{3} & \multirow{4}{*}{ Collaborate } & $\begin{array}{l}\text { 1. Creative Platform } \\
\text { Project }\end{array}$ & 1. Interpersonal \\
\hline & & $\begin{array}{l}\text { 2. Problem based } \\
\text { Learning }\end{array}$ & $\begin{array}{l}\text { 2. Logic } \\
\text { Mathematic }\end{array}$ \\
\hline & & 3. Train The Trainer & 3. Visual Spatial \\
\hline & & \begin{tabular}{|l|} 
4. Freelancer of IT \\
Platform (Netizen testing)
\end{tabular} & \\
\hline \multirow{5}{*}{4} & \multirow{5}{*}{ Connect } & $\begin{array}{l}\begin{array}{l}\text { 1. Social Media } \\
\text { (Telegram) }\end{array} \\
\end{array}$ & 1. Interpersonal \\
\hline & & 2. Online Discussion & \multirow{4}{*}{$\begin{array}{l}\text { 2. Verbal } \\
\text { Linguistic }\end{array}$} \\
\hline & & 3. LMS (U-Learn) & \\
\hline & & $\begin{array}{l}\text { 4. Adobe Education } \\
\text { Exchange } \\
\end{array}$ & \\
\hline & & $\begin{array}{l}\text { 5. Massive Open online } \\
\text { Courses }\end{array}$ & \\
\hline \multirow{4}{*}{5} & \multirow{4}{*}{ Reflect } & $\begin{array}{l}\text { 1. Drag and Drop } \\
\text { Activities }\end{array}$ & 1. Interpersonal \\
\hline & & 2. Crossword Puzzle & \multirow{3}{*}{$\begin{array}{l}\text { 2. Logic } \\
\text { Mathematic }\end{array}$} \\
\hline & & 3. Quizzes & \\
\hline & & 4. Face to Face Discussion & \\
\hline \multirow{3}{*}{6} & \multirow{3}{*}{ Share } & $\begin{array}{l}\text { 1. Adobe Education } \\
\text { Exchange }\end{array}$ & 1. Interpersonal \\
\hline & & 2. Peer Review & \multirow{2}{*}{$\begin{array}{l}\text { 2. Verbal- } \\
\text { Linguistic }\end{array}$} \\
\hline & & 3. Class Presentation & \\
\hline
\end{tabular}

\subsection{Material and Methods}

This study is design for TVET students to collaborate, share the idea and discuss related issue to the context of the subject (Figure 3). This promotes critical thinking and communication skills among students. Participants involved in this study are undergraduate students from two TVET institutions in Malaysia as shown in Table 3.
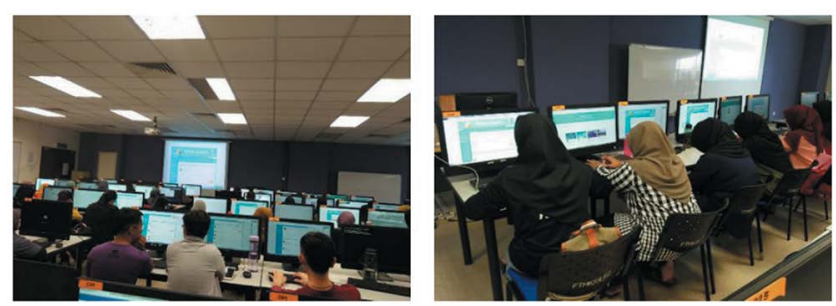

Figure 3. Learning activities using MOOC in classroom.

Table 3. Participants involved in this study

\begin{tabular}{|c|c|c|c|c|}
\hline Group & $\begin{array}{c}\text { TVET } \\
\text { Institution }\end{array}$ & Level & Subject & $\begin{array}{c}\text { No of } \\
\text { Student }\end{array}$ \\
\hline \multirow{5}{*}{$\begin{array}{c}1 \\
\text { (Level 6) }\end{array}$} & Universiti & \multirow{6}{*}{$\begin{array}{c}\text { Bachelor in } \\
\text { Interactive } \\
\text { Media }\end{array}$} & \multirow{6}{*}{$\begin{array}{l}\text { Multimedia } \\
\text { System }\end{array}$} & \multirow{5}{*}{36} \\
\hline & Teknikal & & & \\
\hline & Malaysia & & & \\
\hline & Melaka & & & \\
\hline & (UTeM) & & & \\
\hline \multirow{5}{*}{$\begin{array}{c}2 \\
\text { (Level 3) }\end{array}$} & Kolej & & & \multirow{5}{*}{34} \\
\hline & Komuniti & \multirow{4}{*}{$\begin{array}{l}\text { Certificate in } \\
\text { Information } \\
\text { Technology }\end{array}$} & \multirow{4}{*}{$\begin{array}{l}\text { Fundamental } \\
\text { of Multimedia }\end{array}$} & \\
\hline & Masjid & & & \\
\hline & Tanah & & & \\
\hline & (KKMT) & & & \\
\hline
\end{tabular}

The first group is students from TVET Public University (Level 6) and the second group is Certificate students from TVET Community College (Level 3). The first group consists of 36 students and the second group consists of 34 students.

Aligned with the revolution Education 4.0, this study used Engaging Gamification Massive Open Online Courses (Eg-MOOC) and Learning Management System (LMS) called ULEARN to share teaching and learning materials and stay connected with others. Currently, there are 904 students registered in Eg-MOOC for Multimedia subject. Students from other TVET institutions also collaborate and participate in this platform as mentioned before. The gamified E-Learning site (OMIG) is also embedded into ULEARN, as well as linked to Open Courseware (OCW) and Eg-MOOC. The novelty of OMIG, students can go through the learning process based on student intelligences. The system will guide the students to follow the lesson based on the results from MI Test. Table 4 shows E-Learning Platform with Gamification that have been used in this study. 
Table 4. E-Learning platform with gamification

\begin{tabular}{|c|c|c|}
\hline $\begin{array}{l}\text { E-Learning } \\
\text { Platform }\end{array}$ & Category & URL \\
\hline $\begin{array}{l}\text { Eg-MOOC } \\
\text { (Open } \\
\text { Learning) }\end{array}$ & Public & $\begin{array}{c}\text { https://www.openlearning. } \\
\text { com/courses/multimedia- } \\
\text { system } \\
\text { https://www.flipsnack. } \\
\text { com/995DFECF8D6/a-mooc- } \\
\text { multimedia-system.html }\end{array}$ \\
\hline $\begin{array}{l}\text { Learning } \\
\text { Management } \\
\text { System } \\
\text { (Moodle) }\end{array}$ & Private & $\begin{array}{c}\text { http://ulearn.utem.edu.my/ } \\
\text { https://www.flipsnack. } \\
\text { com/995DFECF8D6/c-ulearn- } \\
\text { usage.html }\end{array}$ \\
\hline $\begin{array}{c}\text { Open } \\
\text { Courseware } \\
(\mathrm{OCW})\end{array}$ & Public & $\begin{array}{l}\text { http://ocw.utem.edu.my/web/ } \\
\text { course/view.php?id=21 }\end{array}$ \\
\hline $\begin{array}{c}\text { Online } \\
\text { Mutliple } \\
\text { Intelligences } \\
\text { Gamification } \\
\text { (OMIG) }\end{array}$ & Public & $\begin{array}{l}\text { http://onmitt.net/omig/index. } \\
\text { html } \\
\text { https://www.flipsnack. } \\
\text { com/995DFECF8D6/a-online- } \\
\text { delivery.html }\end{array}$ \\
\hline $\begin{array}{c}\text { Mobile } \\
\text { Gamification } \\
\text { Leaderboard } \\
\text { (MGLeB) } \\
\text { (Android) }\end{array}$ & Private & $\begin{array}{l}\text { http://www.mgleb.smartgreen. } \\
\text { my/ } \\
\text { https://play.google.com/store/ } \\
\text { apps/details?id=my.odekan. } \\
\text { mgl eblec\&hl=en }\end{array}$ \\
\hline
\end{tabular}

Figure 4 shows the flowchart for adaptive learning with gamification. In order to identify students intelligences, students need to answer few questions. In a few minutes, system shows the percentage of each intelligences. Students also can choose her/his mentor before start learning and systems will suggest a learning path for students based on highest mark.

\section{The Challenges, Outcomes, Evaluations and Achievements}

This part discussed about the three challenges during the case study, outcomes, evaluations used in this study and student achievements.

\subsection{The Challenges}

There are three challenges that have been identified in this study:

\subsubsection{Student Background}

It was really challenging to manage and provide suitable activities to student with different level and institution. Cooperation from each institution is needed to ensure students can develop high level skills and are knowledgeable. Taking the first step by using adaptive learning with gamification is the best move for all parties. With a proper design, learning activities can be efficient in providing motivation for students driving engagement. The mission design must be average level. The activities are above-average skill level to make students keen to learn. Table 5 shows Course Learning Outcome (CLO) Achievement. Finding shows that the percentage of student achievement is not achievable where students still cannot understand multimedia subjects well. Hence, these students need to be guided and given the opportunity to communicate with students from other institutions. Indirectly can help students to improve their knowledge and motivate them to learn.

Table 5. CLO achievement

\begin{tabular}{|c|l|c|c|c|}
\hline \multirow{2}{*}{ CLO } & \multicolumn{1}{|c|}{ CLO Statement } & \multicolumn{2}{|c|}{$\begin{array}{c}\text { Student } \\
\text { Achievement }\end{array}$} & \multirow{2}{*}{ Note } \\
\cline { 3 - 4 } & Target & Achieved & \\
\hline CLO1 & $\begin{array}{l}\text { Explain well the basic } \\
\text { concept of multimedia }\end{array}$ & 80.00 & 60.00 & $\begin{array}{c}\text { Not } \\
\text { Achieved }\end{array}$ \\
\hline CLO2 & $\begin{array}{l}\text { Edit multimedia element } \\
\text { using suitable software }\end{array}$ & 80.00 & 50.00 & $\begin{array}{c}\text { Not } \\
\text { Achieved }\end{array}$ \\
\hline CLO3 & $\begin{array}{l}\text { spreading multimedia } \\
\text { presentation using } \\
\text { suitable medium }\end{array}$ & 80.00 & 60.00 & $\begin{array}{c}\text { Not } \\
\text { Achieved }\end{array}$ \\
\hline
\end{tabular}

\subsubsection{Variety Learning Materials}

In certain situations, most of educators lacked of innovative ideas to design interactive teaching and learning activities in classroom that can suit students' strength. As a result, students become tense and less motivation. Thus, students would perceive learning as a force and thus this will be difficult for educators to educate gifted students as well as to create the potentials for the country. Implementing gameful design into an educational website can overcome these problems.

\subsubsection{Gameful Design Activities}

21st century, educators also faced with the younger generation that is highly skilled in ICT and exposed to 


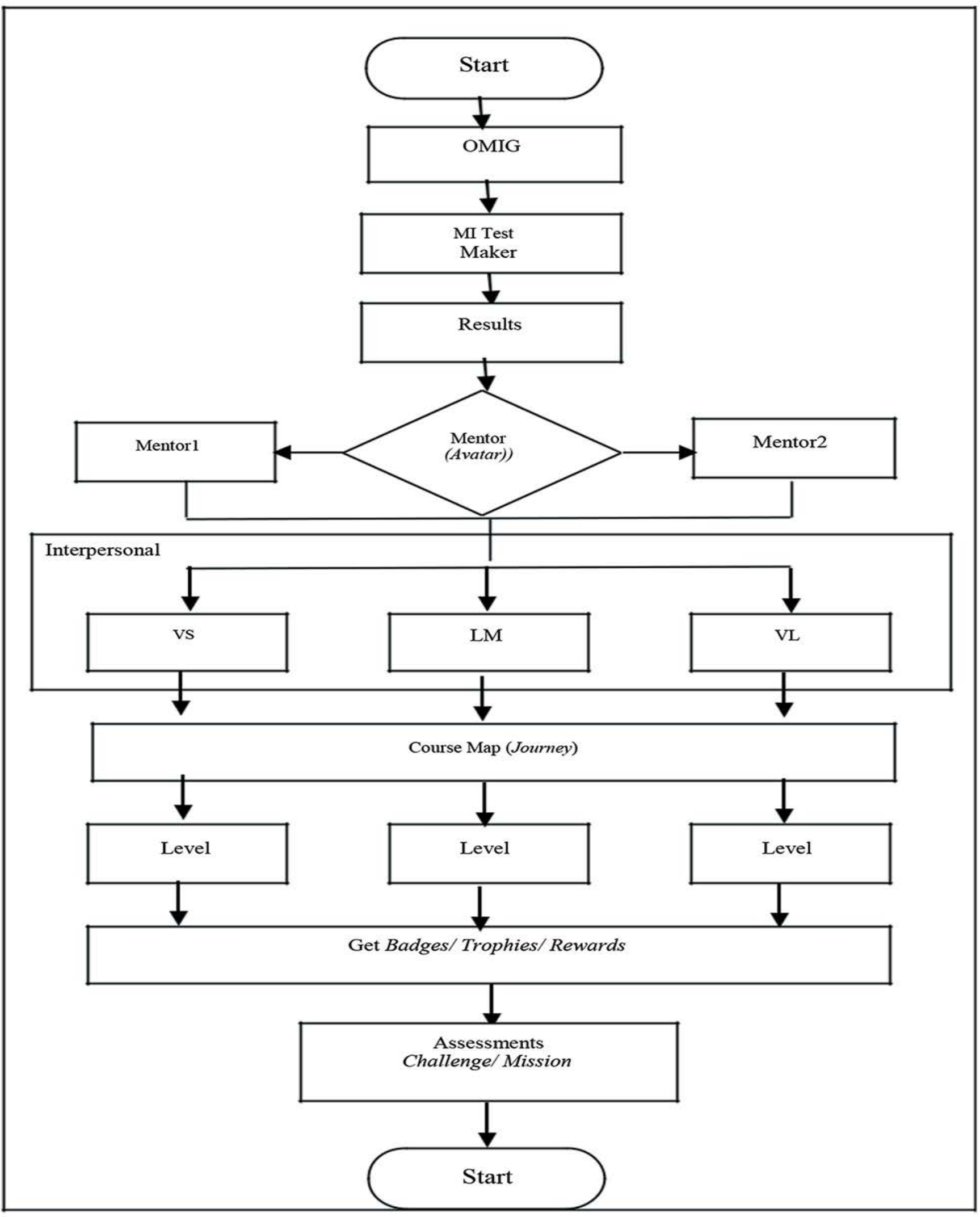

Figure 4. Flowchart for adaptive learning with gamification. 
source of information. In ${ }^{16}$ did mention that most of the educator applies gamification as a tool for engagement and motivation. In order to adapt gamification efficiently, educators need to understand suitable game elements that can be used in teaching and learning process either it provides intrinsic or extrinsic motivation. Incorporating fun elements in learning activities is a good alternative to engage students learning. Learning should be challenging so it needs student to think deep and cannot be achieved by guessing. Students need to collaborate with team members to achieve the mission given. Students are able to learn with each other's and improve their task until complete their mission.

\subsection{Outcomes}

This part is to determine whether learning outcomes have been achieved or not. The competencies and students' skills are also identified. Students need to be involved in what and how they learn. Evaluation from peer review and grading allows student to learn from each other's. Educators can apply leader board to display ranks of all participation in the learning for comparison. Assignments are known as mission and challenge where students have to complete the mission and claim the rewards. The learning outcomes achieved include:

\subsubsection{Develop Collaborative Work Strategies across Network}

Students learn to work in team in order to complete the mission given (Figure 5). Students will get point of each task and can claim the reward. It is a good approach to connect with team members as well as to gain experience and improve their skills. At the same time, students learn on how to work cooperatively with partners and understand their roles.
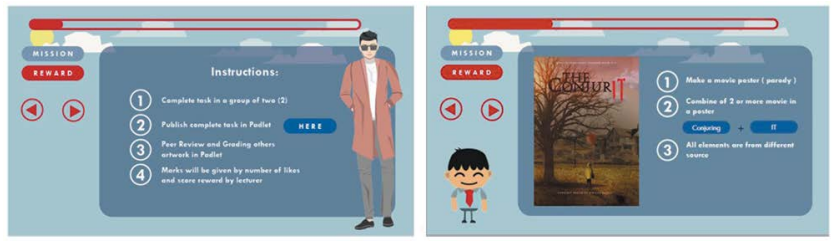

Figure 5. Mission.

\subsubsection{Motivated More by a Failure than Success}

When playing game, a player could lose a life and required to start over. In learning process also, student can try over and over again to improve their work quality. So student will pay closer attention, more focused and engage with the task given.

\subsubsection{Enhance Written Communication Skills}

Figure 6 shows sample of discussion through example MOOC. Students give their opinion, sharing related documents and link as well as upload related learning materials. From this activity, other students can read and responses to each other's. Class can still active everywhere and anytime.

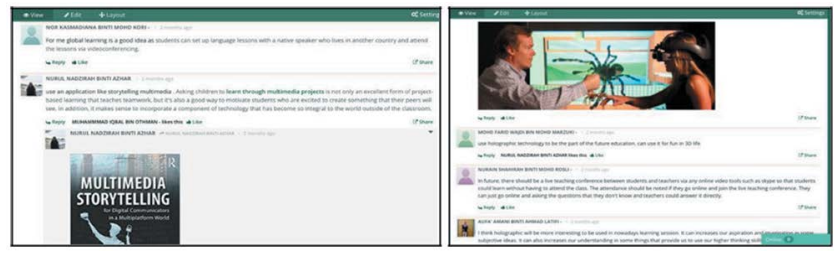

Figure 6. Online discussion via Eg-MOOC.

\subsubsection{Be Entrepreneurial}

Students also trained as trainers and act as facilitator. Sharing knowledge to others and involved with the real project. In this study, student can identify suitable job through creative platform like Design Crowd and up work. As a reward, students will get payment from client via Paypal.

\subsection{Evaluation}

\subsubsection{Point and Reward}

In this study, students get the points based on the date of submission. Students need to submit task before due date given and get a point. Students are also encouraged to submit early to get more point. Figure 7 shows that at the end of the task, student can claim the reward to improve the percentage of carry marks as well as get bonus point if students get highest score.

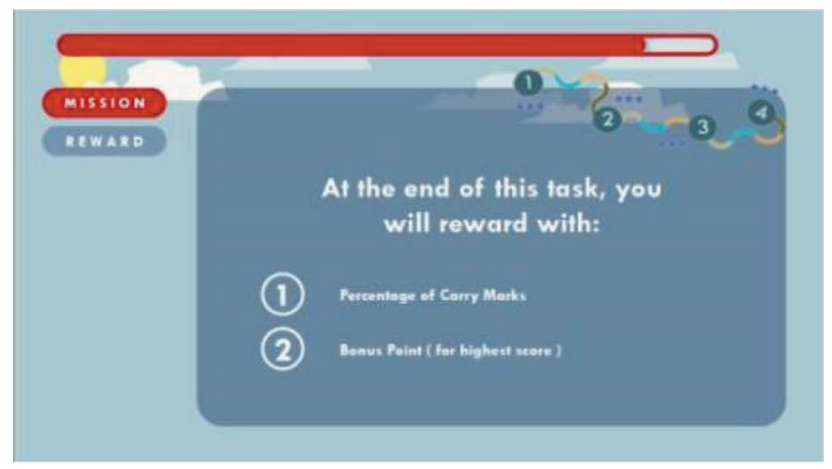

Figure 7. Online discussion via Eg-MOOC. 


\subsubsection{Peer Grading}

In this study, students are required to evaluate and comment other student's task. Scores are given from 1-9 as shown in Figure 8. From the comments, students can improve their work and get the rank.

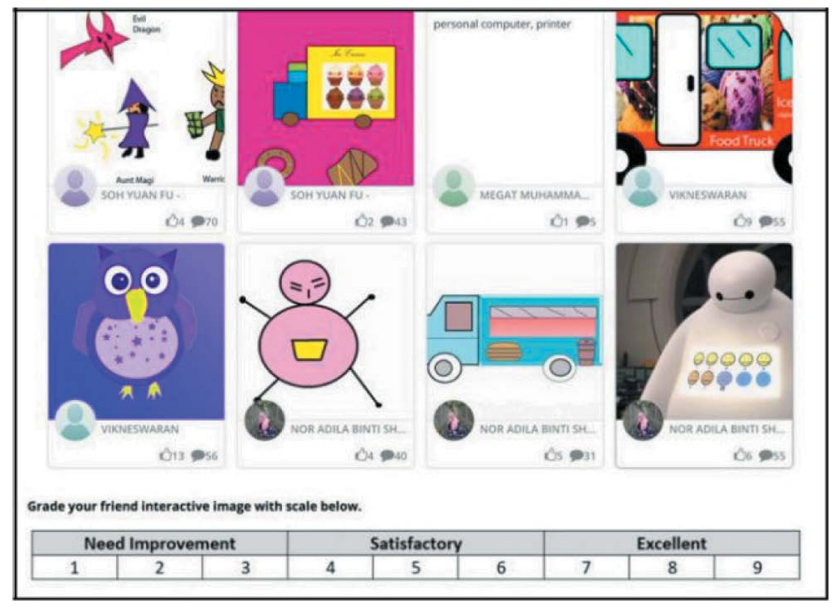

Figure 8. Peer grading.

\subsection{Achievements}

Activities in class were use real project as an alternative assessment. Students are rewarded and won several award in E-Learning competition as well as have opportunities to reflect their learning in order to help them develop critical thinking skills. Table 6 shows the list of student achievement for this study.

Table 6. Students Achievement

\begin{tabular}{|c|c|c|c|}
\hline No & Event/ Platform & Organizer & Award \\
\hline \multirow{2}{*}{1.} & \multirow{2}{*}{$\begin{array}{l}\text { FTMK Final Year } \\
\text { Project Showcase } \\
2017\end{array}$} & \multirow{2}{*}{ FTMK, UTeM } & $\begin{array}{l}1^{\text {st }} \text { Runner Up } \\
\text { (Best Product), }\end{array}$ \\
\hline & & & $\begin{array}{l}2^{\text {nd }} \text { Runner Up } \\
\text { (Best Presenter) }\end{array}$ \\
\hline \multirow{3}{*}{2.} & \multirow{3}{*}{$\begin{array}{c}\text { E-Learning Carnival } \\
2017 \text { (ELC 2017) }\end{array}$} & \multirow{3}{*}{ PSTP, UTeM } & $\begin{array}{l}\text { I }^{\text {st }} \text { Innovation } \\
\text { Prize } \\
\end{array}$ \\
\hline & & & 3 Gold Award \\
\hline & & & 3 Bronze Award \\
\hline 3. & $\begin{array}{c}\text { International } \\
\text { University Carnival } \\
\text { on eLearning } \\
\text { (IUCEL 2017) } \\
\end{array}$ & $\begin{array}{l}\text { MEIPTA, } \\
\text { Malaysia }\end{array}$ & Gold Award \\
\hline 4. & $\begin{array}{l}\text { Collage Design } \\
\text { Competition }\end{array}$ & MBMB, Melaka & $\begin{array}{c}\text { Finalist } \\
\text { (7 students) }\end{array}$ \\
\hline \multirow{2}{*}{5.} & \multirow{2}{*}{$\begin{array}{l}\text { Creative Design } \\
\text { Platform/ IT } \\
\text { Platform }\end{array}$} & Netizen Testing & Acceptance \\
\hline & & Design Crowd & Acceptance \\
\hline
\end{tabular}

\section{Conclusion}

Successful gamification needs to adapt as per students' intelligence and provide suitable teaching materials to mastery their skills. Adaptive Learning strategies with gamification need to be applying in teaching and learning activities to enhance student engagement. In future, creative educators are able to update the digital content easily and make students enjoy learning and also use the appropriate 4.0 technology.

\section{Acknowledgement}

This initiative is conducted in collaboration with research group Pervasive Computing and Educational Technology (PET), Center for Advanced Computing Technology (C-ACT), Universiti Teknikal Malaysia Melaka (UTeM).

\section{References}

1. Gok A, Brendan C. A New Way of Gamification a Course in Online Higher Education. SITE. 2016; 4011-4017.

2. McGrath N, Bayerlein L. Engaging online students through the gamification of learning materials: The present and the future. Australasian Society for Computers in Learning in Tertiary Education. 2013; 1-5.

3. Mohamad SNM, Sazilah S, Norasiken B. An Analysis Of Gamification Elements In Online Learning To Enhance Learning Engagement in Zulikha, J. \& N. H. Zakaria (Eds.). Proceedings of the 6th International Conference on Computing \& Informatics. 2017; 452-460.

4. Mohamad SNM, Nur SSS, Mohd AMS. Gamification Approach in Education to Increase Learning Engagement. Int. j. humanit. arts soc. sci. 2018; 4(1): 22-32. https://doi. org/10.20469/ijhss.4.10003-1.

5. Gardner H. Frames of Mind: The Theory of Multiple Intelligences. New York: Basic Books, INC. 1983.

6. Wu Q, Yueming Z, Zongwei L. A Gamification Approach to Getting Students Engaged in Academic Study. 2015; 17(4): 26-29.

7. Gonzalez CS, Pedro T, Vanesa M. Enhancing the Engagement of Intelligent Tutorial Systems through Personalization of Gamification. Int. J. Eng. 2016; 32(1B): 532-541.

8. Mohamad SNM. Model for Online Teaching Tools Based on Interpersonal, Visual and Verbal Intelligence. Doctoral dissertation, UTeM. 2014.

9. Barata G. So Fun It Hurts- Gamifying an Engineering Course. Foundations of Augmented Cognition. Springer. 
2013; 639-648. https://doi.org/10.1007/978-3-642-394546 68.

10. Chauhan J, Taneja S, Goel A. Enhancing mooc with augmented reality, adaptive learning and gamification. In IEEE 3rd International Conference on MOOCs, Innovation and Technology in Education. 2015; 348-353. https://doi. org/10.1109/MITE.2015.7375343.

11. Darejeh A, Salim SS. Gamification solutions to enhance software user engagement systematic review. INT J HUMCOMPUT INT. 2016; 32(8) 613-642.

12. Daud R, Sazilah S, Siti NMM, Azizul MY. Modelling a Mobile Gamification Model to Increase Student Engagement: An Analysis using Analytic Hierarchy Process. Advanced Science Letters. 2016; 23(9): 8707-8712. https://doi.org/10.1166/asl.2017.9955.

13. Yusoff A, Sazilah M, Siti S, Daud NMM. Gamification element Through Massive Open Online Courses in TVET:
An Analysis using Analytic Hierarchy Process. Advanced Science Letters. 2016; 23(9): 8713-8717. https://doi. org/10.1166/asl.2017.9956.

14. Blaschke LM, Stewart H. Heutagogy: A Holistic Framework for Creating Twenty-First-Century Self Determined Learners. Lecture Notes in Educational Technology. Springer. 2016; 25-40. https://doi.org/10.1007/978-3-66247724-3_2.

15. Gros B. The Future of Ubiquitos Learning. 2016. https://doi. org/10.1007/978-3-662-47724-3.

16. Dichev C, Darina D, Galia A, Gennady A. From Gamification to Gameful Design and Gameful Experience in Learning. Cybernatics and Information Technologies. 2014; 14(4): 80-99. https://doi.org/10.1515/cait-2014-0007. 